\title{
ECHO-QUESTIONS AND THEIR IMPORTANCE IN THE SPEECH
}

\section{Artemenko A. I.}

\section{INTRODUCTION}

Echo-questions are a specific type of interrogative sentences and can be characterized emotionally. Their usage depends on the pragmatic situation that is between speakers of the dialogue and expresses the context and the character of the speech of these speakers. Echo-questions are characterized by the special modality. They can be characterized as the kind of subjective modality and constitute the relation of the speakers to the reality reflected in the dialogue.

Echo-questions are mainly used in dialogues and characterized by a particular pragmatic modality which shows that the speech is pragmatic.

The research of importance of echo-questions in speech is very actual in linguistic now. This research is researched by the following scientist as Arutyunova N.D., Rubinshtein S.L., Serl R.DG., Chkhetiani T.D., Barabanshchykova O.Yu.

This research is important because it is not only limited to its grammatical analysis but it is important because this research includes the pragmatic aspect of their usage in the speech.

There are different types of echo-questions in the speech which follow different intentions of the speakers which influences on the attitude of speakers to each other.

We can admit that the dialogue can be divided into the dialogue unities represented by specific elements which connect pragmatically. Echoquestions can be used when we want to repeat some expressions of the dialogue showing our attitude to the content of the speech.

Echo-questions which can be considered according to the structural and semantic aspects in the speech can repeat the previous expression which can be expressed by different parts of speech.

The usage of echo-questions makes possibility to realize the more complicated inner state of speakers. They can express positive and negative meanings, such as joy, admiration, wonder, clarification, denial, angry and etc.

The comparative method and methods of synthesis and analysis were used in our research. Scientific novelty of the research includes different classification of echo-questions according to the pragmatic aspect.

The purpose of the article is to analyze echo-questions according to the pragmatic aspects and to show their ability to express the diplomatic abilities 
to make speech more polite. Echo-questions points out their features and the importance of their usage and their intensifiers which makes the speech rich. The article aims to address the pragmatic and linguistic features of echoquestions in the speech classifying them according the pragmatic aspect of speech. We can admit that sometimes the lack of time for correlation of the speech and the inability to return to the first expression creates the need for the usage of echo-questions in the speech which makes it pos sible to analyze according to the pragmatic aspects.

The importance of using echo-questions as a means of avoiding conflict and expressing politeness is discussed in this article.

This article indicates the diplomatic nature of echo-questions and shows that echo-questions can be used in the speech to clarify the information and filling of communicative pauses.

\section{Pragmatic aspect of echo-questions}

Pragmatic aspect is inherent in speech of different languages. It is also inherent in English language too. We can admit that pragmatic aspect of echo-questions is due to the fact that during the speech speakers not only transmit and receive certain information but also influence on each other with different intensity ${ }^{1}$.

Echo-questions can be analyzed according to the pragmatic aspect of the speech.

It is natural to have a pragmatic aspect that allows you to evaluate additional information about speakers, forms of speech and the usage of echo-questions in the speech.

Echo-questions in pragmatic speech are used to convey the inner emotions and feelings of the speakers, which helps them communicate more deeply. Echo-questions as pragmatic and linguistic means can help speakers express their inner state.

We can admit that pragmatics deal with the choice of linguistic means for the best expression of feelings, to effectively influence of addressee and it is quite logical that the central category of contemporary pragmatics is the subject category of the speaker's relation to what and how he speaks ${ }^{2}$.

Echo-questions can reproduce the speaker's inner state, influence on the organization of communication and the structure of the speech act.

In speech the speaker's action are aimed at communicating to the addressee and informing him about his actions and find out the essence of what he is informed.

1 Серль Р.Дж. Косвенные речевые акты. Новое в зарубежной лингвистике. Москва, 1986. Вып. 17. С. 195-222. DOI.811.11

2 Арутюнова Н.Д. Диалогическая цитация (К проблеме чужой речи). Вопросы языкознания. 1989. № 1. C. 50-64. DOI.811.111'42(075.8); Чхетиани Т.Д. Контакто поддерживающая функция метакоммуникативных вопросов. Bысказывание и дискурс в прагмалистическом аспекте. Киев, 1989. С. 100-103. DOI.81'367.322 
In the dialogue:

Cardin. Don't let's talk anymore. Let's forget and go ahead.

Karen. (puzzled). Go ahead?

Cardin. Yes, Karen.( Hellman)

echo-question Go ahead? expresses misunderstanding.

The next dialogue:

Tenny. Yes. Faye told me.

George. Faye?

Jenny. Faye Medwick. She's the one pushing from my side. (Simon)

Includes the echo-question Faye? which is used for clarification of the information.

According to the pragmatic aspect of the speech echo-questions can be divided into the following groups:

1) meta-communicative echo-questions which express the inner state of the speaker (positive and negative emotions and feelings).

The next dialogue:

"You're thick with him sometimes", said old man, turning on me. "Hasn't he told you all about it?"

"Me?" I said. "No".

"Mind you , the whole thing's not to be wondered at", said the old man. "front and back doors never licked, and money kept in the hose. That's terrible temptation to anyone with a weakness that way. A temptation that shouldn't have been put [Pearce: 14]

Includes the echo-question $M e$ ? which is used to express the inner state of the speaker.

The next dialogue:

- I think you have been drinking, Mr. Carton.

- Think? You know I have been drinking.

- Since I must say so, know it [Dickens: 102]

includes the echo-question Think? which expresses the inner state of the speaker too.

The next dialogue:

- Turk. YES, he does. If you ask me, he's jealous.

- Marie. Jealous?

- Turk. I've always thought he had a crash on you [Inge: 268]

includes an echo-question Jealous? which is used to express astonishment.

In the next dialogue:

Secretary. Well, you can help wake them. What's your name? I'll make out your card.

Yank. (confused) Name?

Secretary (sharply). Don't you know your name? [Neil: 73]

the echo-question expresses such inner state of the speaker as confusion and astonishment. 
In the next dialogue:

Abby (jerking her hands away - harshly). So, you are planning to leave the farm to Eben. Aren't you?

Cabot. Leave...?

the echo-question Leave... ? expresses astonishment too.

In the next dialogue:

Junior. It's about those evictions, father. Don't you think we're being too harsh?

I mean, maybe we should show them a little kindness.

Pinchley. Kindness?(He swings his come savagely. Junior ducks just in time) This is a bank, son, not a mother! [Simon: 35]

The echo-question Kindness? expresses such inner state of the speaker as irritation.

In the next dialogue:

Marco. (hesitatingly). I know it's a great honor, sir - but, forgetting the soul side of it, I've got to it.

Kablai (astonished) To eat?

Marco. I mean I'm ambitious, I've got to succeed, and - ( suddenly blurts out).What can you pay me? [O'Neil: 229]

The echo-question To eat? expresses such inner state of the speaker as astonishment.

In the next dialogue:

Biff. Where'd you do this time, dad? Gee, we were lonesome for you.

Willy (pleased, puts an arm around each boy and they come down to the apron). Lonesome, heh?

Biff. Missed you every minute. [Gassner: 11]

The echo-question Lonesome, heh? expresses astonishment too but at the same time the speaker is pleased.

In the next dialogue:

Nick. Say I wanted to buy one of these.

Jonathan. You? One of those?

Nick. Mm. What would I do? [Margulies: 347[

The echo-questions You? One of those? are used to express interest of information.

In the next dialogue:

Ann. Then do what you have to do!

Chris. Do what? What is there to do? I've looked all night for a reason to make him suffer.

Ann. There's the reason, there's a reason! (Miller:15)

The echo-question Do what? expresses astonishment and indignation.

In the next dialogue:

Sheryl: Says everyone. He's a fraud - like you .

Kenny. I'm a fraud, am I? 
Sheryl: Face up to it, Kenny! We don't mix well. We're like oil and, water. It doesn't work for us! [Allow: 83]

In the next dialogue:

Ruth (At the phone) Hello - just a minute. (goes, to door) Walter, it's Mrs. Arnold.( waits. Goes back to the phone. Tense) hello. Yes, this is his wife speaking... He's lying down now. Yes... - I know. We should have called, but we were so sure he'd be able to come in today. Yes-yes, I'm very sorry. Yes... Thank you very much (she hangs up. Walter is standing in the doorway of the bedroom behind her).That was Mrs. Arnold.

Walter (indifferently).Was it?

Ruth. She said if you don't come in tomorrow that, they are getting a new man...(Hansberry: 168)

The echo-question Was it? expresses astonishment .

In the next dialogue:

Billy. You've been most pleasant with me, ser.

Claggfrt. Have I?

Billy. Yes, sir, in the mess, the day I came abroad? And almost every day you have a pleasant word (Coxe: 375)

The echo-question Have I? expresses astonishment and joy.

In the next dialogue:

Macon: oh, daisies aren't my favorite flowers. My favorite flowers are tulips.

Bess. Tulips?

Macon: They grow in this country called Holland. They're the most beautiful flowers in the world. Daisies don't compare. Why, daisies are really nothing more than common weeds. (Henley: 41)

the echo-question Tulips? expresses astonishment and denial.

In the next dialogue:

Christine: (still suspiciously - with a touch of scorn) if I loved anyone - !

Christine: tauntingly) If? I think you do love him - as much as you can love! ( With a sudden flurry of jealousy) You little fool! Don't you know I made him flirt with you, so you wouldn't be suspicious?

Lavina: (gives a little shudder - then fiercely) He didn't fool me! I just led him on - to find out things! I always hated him!...(O’Neil: 689)

the echo-question If? expresses mockery and irritation.

Echo-questions can express such inner state as fear.

And the next dialogue:

- Berenece. Why, candy everybody has to die.

John Henry. Everybody? Are you going to die, Frankie?

Frankie. I doubt it. I honestly don't think I'll ever die (Cullers: 191)।

Includes the echo-question Everybody? that is used to express the fear.

Echo-questions can express agitation. The next dialogue:

Benny. When Ma tells him the lies about us -

Emma( excitedly).What lies? 
Benny. I am goin' to repeat them (O'Neil: 237-238)

shows the echo-question What lies? expresses agitation according to the information of Benny.

We can admit that echo-questions can express pain. The next echoquestion another portrait? which is used in the dialogue:

Nick... (Suddenly) How are you going to let me do another portrait of you?

Constance (laughs). Another portrait? No, no, indeed. I want to remember myself as I was in the picture upstairs.

Nick. Go and get it for me. I want to look at it with you. (Hellman: 217)

expresses the inner pain of the speaker though she is laughing.

In the next dialogue:

Yank. After I'm 'nitiated. I'll show you.

Secretary (dis appointed )Initiated ? There's no initiation.

Yank (disappointed). Aren't there no password... (O. Neil: 74)

echo-question Initiated? expresses dis appointment.

In the next dialogue:

Biff. I'm leaving early tomorrow.

Happy. He's going to see Bill Oliver.

Willy. (interestedly) Oliver? For what?

Bill. (with reserve) He always said he'd stake me. I'd like to go into business, so maybe I can take him up on it.

Linda. Don't interrupt. What's wonderful about it? There's fifty men in the City of New York who'd stake him. (Miller: 22)

the echo-question Oliver? expresses interest.

In the next dialogue:

Conover. Yes, I'm afraid it would be. It would defeat the whole purpose.

Mary. Purpose? What purpose?

Conover (avoiding a direct answer). Mrs. Matthews, you must know how concerned your husband is about this country's splitting apart - how deeply he feels that it must be held together. (Gassney : 84)

echo-question Purpose? expresses astonishment and the post echoquestion What purpose? clarifies information.

Analyzing this dialogue we can admit that this echo-question not only expresses astonishment but clarify the information too.

The next type of echo-questions is

2) echo-questions which clarify the information.

In the dialogue:

Mannon. Wait! I'm sorry I said. It isn't my heart. It's something uneasy troubling my mind - as if something in me was listening, watching, waiting for something to happen.

Christine. Waiting for what to happen?

Mannon. I don’t know...(O’Neil: 715) 
echo-question Waiting for what to happen? is used for clarification of information.

In the next dialogue:

- Mother thought I need a rest, when I get back we'll probably either sign up with the First National or keep on with Famous.

- Who's we ? (Frizgerald: 53)

echo-question Who's we? is used for clarification of the information too.

In the next dialogue:

Frenchy: You got a lot to lean, Cleo. What's between you?

Cleo. Between you? _Who?

Frenchy. Or don't you speak without your lawyer? (Coming up closer to her and dropping his voice). Listen, don't twist Star's head. He's foolish, but he's good and we like him. Don't get him in trouble. (Taking her arm) Come on over my office. (Odets: 382-383)

the echo-question Between you? expresses the astonishment and clarify the information.

The next type of echo-questions is

3) echo-questions which are used for filling of communicative pause.

In the next dialogue:

Sexton. Ten years.

Kuryatin. Ten years?

Sexton. Since yesterday morning it seems like ten years. I must have sinned terribly to deserve this. God must have dropped all other business, to punish me this way. Where is the doctor? (N. Simon: 415)

echo-question Ten years? is used for clarification information and at the same time for filling of communicative pause.

In the next dialogue:

"Poor colonel Carey. After all those years in South America he deserved to live longer and enjoy a few years of retirement.

"South America?" harry murmured, trying not to let his eyes light up with sudden hope. (Yakubovsky: 52)

echo-question South America? expresses astonishment and used for filling of the communicative pause.

We can admit that echo-questions which are of different types of speech can be used for expressing politeness of the speech and it is very important.

\section{Echo-questions as a politeness means of speech}

Politeness is researched by different researches differently. According to the Longman Dictionary of Contemporary English word "polite" has three meanings:

1) polite as civil or socially correct;

2) polite as kind or friendly;

3) polite as tactful or diplomatic.

Formulas of politeness can be associated with diplomacy. 
Speech can be more diplomatic and polite when we use echo-questions in it. According to the linguistic criteria politeness can be pragmatic. It means that which is polite to the addressee would be incorrect to the speaker.

There are three main types of politeness:

1) positive politeness (an expression of solidarity);

2) negative politeness (an expression of restraint);

3) secret politeness (off record politeness) ${ }^{3}$.

Positive and negative politeness correlates with polite and impolite illocution. And secret politeness tries to avoid imposing thoughts.

Positive and negative politeness correlates with polite and impolite illocution and, accordingly, speech acts. Suggestions, invitations, greetings, gratitude, etc. are examples of speech acts. Speech acts of order, demand, request, etc. differ in the nature of the interaction of their illocutionary purpose according to their speech goals and in the degree to which they affect to personality of the addressee. In term of the relationship between the pragmatic intentions of the speech act and the pragmatic intention of establishing and maintaining politeness. There are four types of speech acts, such as 1) rivalries represented by directives (orders, questions, requests and etc.) whose illicit purpose competes for a social purpose; 2) politeness represented by certain types of commissions and expressive (invitation, offer, greetings, congratulations, gratitude, apology, etc., whose illocutionary purpose coincide which the social purpose); 3) indifferent, which include statements, messages, information, i.e. statements-constants, their illocutionary purpose irrespective of the social purpose. One of the characteristic features of polite speech acts is the variation in the degree of politeness, which is conditioned by the status characteristic of the speakers and the sphere of speech ${ }^{4}$.

According the types of speech and politeness in speech we can distinguish the following types of echo-questions: 1) echo-questions directives, that can express order, requests, demands, etc.; 2) echo-questions that can express politeness; 3 ) echo-questions constative without the social purpose, such as echo-questions which are used for filling of communicative pause and echo-questions which clarify the information; The following dialogue:

Julie: Why don't you sell your television\&

Celia: Sell my television? I don't know. I never thought of that. It costs four thousand dollars, you know.

3 Чхетиани Т.Д. Контакто поддерживающая функция метакоммуникативных вопросов. Высказывание и дискурс в прагмалистическом аспекте. Киев, 1989. C. 100-103. DOI.81'367.322

4 Барабанщикова О.Ю. Перепит як стимулятор розвитку діалогу. Проблеми зіставної семантики. Київ, 1999. С. 355-357. DOI.811.111.42(075.8). 
Julie: Four thousands dollars? Where would you get four thousand dollars!? (Shapp: 33)

shows that echo-question e Sell my television ?expresses astonishment and requests and an echo-question Four thousands dollars? emphasize this intention.

In the next dialogue;

"Don't you think that she's the most wonderful women in the world?

Said Paul." Wonderful? In what way?"(Waugh: 127-128)

Echo-question expressive Wonderful? expresses its objection denial to what the previous speaker said about a women he thinks that she is the best in the world. But the other speaker disagrees with this statement and in order not to offend the opinion of the speaker the speaker uses echo-question and at the same time the intensifier of the echo-question which intensifies the intensity of expressing the politeness of the echo-question.

In the next dialogue:

"A what!" exclaimed Mr. Pickwick.

"A bail", replied Perker.

"A bail?"

"Yes, my dear Sir, half a dozen of them here. Bail you to any amount, and only charge half-a-crown. Curious trade isn't it? Said Perker, regaling himself with a pinch of snuff. (Dickens: 635)

echo-question A bail? expresses the denial.

Echo-questions which can express politeness are echo-questions which are used for clarification of information and echo-questions-placeholders of communicative pauses. And we can admit that they are the most spread group of echo-questions in the speech.

The following dialogue:

"She asked me to." - said Lucy "and she's really very sweet."

"Sweet?"

"She was absolutely sweet to me yesterday." (Waugh: 336 )

shows that echo-question Sweet?" expresses clarification of information. The speaker wants to clarify information because he doesn't want to be impolite and echo-question is helping him.

The other dialogue:

"And I said , as soon as the priest finishes."

"And the priest?"

"I don't know", I told him and I saw his face working and the seat coming down on his forehead." I have never killed a man". (Hemingway: 37)

Includes the echo-question Sweet? which expresses astonishment and at the same time shows that the speaker is trying to be polite.

In the next dialogue the echo-question constative, which do not have social purpose, is used for filling of communicative pauses: 
"Advising them in time, it should be possible to unite fifty rifles of a certain dependability".

"How dependable?

"Dependable within the gravity of the situation. (Hemingway: 65)

The next dialogue :

"Where do you think we should go?" Pilar asked.

"Where?"

"Yes, where." (Hemingway: 178)

shows that echo-question Where? is used for filling of communicative pause to. And it is helping the speaker not to have conflict situation.

If the speaker doesn't want to be rude he can use echo-question in his speech. It allows him to continue the conversation and keeps friendly atmosphere in the process of communication. The next dialogue shows this:

"What for ?said Tom. "I don't want your money. I've got a great deal more money than you, because I'm a boy. I always have half - sovereigns and sovereigns for my Christmas boxes, because I shall be a man, and you only have five- shilling pieces, because you're only a girl".

"Well, but , Tom - if mother would let me give you two half - crowns, cent, a sixpence out of my purse to put into your pocket and s pend you know and buy some more rabbits with it."

"More rabbits? I don't want any more."

“Oh, but, Tom, they're all dead.”( Eliot:54)

In the dialogue:

Ruth. Oh, Walter... (softly) Honey, why can't you stop fighting me?

Walter 9 without thinking). Who's fighting you? Who even cares about you?

(This line begins the retardation of his mood).

Ruth. Well - (she waits a long time, and then with resignation starts, to put away her things ) I guess I might as well go on to bed,... (more or less to herself) I don't know where lost it ... I guess, I just didn't really realize (She sturts out to the bedroom and stops) You want some hot milk?

Walter: Hot milk?

Walter: Hot milk?

Ruth: Yes - hot milk.

Walter; Why hot milk?

Ruth: 'Cause after all that liquor you come something hot in your stomach.

Walter: I don't want no milk (Hansberry: 158-159)

echo-question Hot milk? is used for clarification of information.

We can admit that in the process of communication we can interrupt the speaker but at the same time we can be polite using echo-questions.

In the next dialogue:

- they've probably got orders to shut down on it. I.D.C. Have got the B.B.C. In their pocket. 
- I.D.C.?

- Imperal Defence College. They're the new hush-bush cryptofascist department. They're in up to the neck with I.C.I. And the oil companies.

- I.C.I.?

- Imperal chemicals (Waugh: 302)

echo-questions I.D.C.? And I.D.C.? are used for clarification of information and help speakers to be polite.

In the next dialogue:

"Dorian Gray's ...- we shall all suffer for what the gods have given us, suffer terribly"

"Dorian Gray? Is that his name?" asked Lord Henry...(Wild: 10)

echo-question Dorian Gray? Is used for clarification of information and the next question Is that his name? intensifies the intention of echo-question to express astonishment.

\section{The intensification of echo-questions}

Intensification is defined as a linguistic expression characterized by multiple polar increases or decreases.

Intensity category is understood as "the semantic category, the essence of which is to express the degree of manifestation of a characteristic, as well as in the logical separation, to accentuate the individual parts of expression".

Intensity is regarded as conceptual category that serves to reflect gradations in the degree of expression of a feature and is expressed by means of different linguistic level ${ }^{5}$.

Intensification is considered appropriate and legitimate amplification as pragmatic category intended to increase the logic effectiveness of echoquestions and their influence on the speech.

Analyses of intensification of echo-questions give us the ability to note that they act as a means of changing of the degree of their expressiveness.

Expressiveness as category of speech means understanding of explicit or implicit way of linguistic means to perform an imaginative and expressive function during the speech. It also refers to the amplification of the signal of approval and dis approval of the expressiveness.

Expressiveness also refers to the amplification of the signal of approval or dis approval of the existing state of affairs by the speaker and perception [3].

Summarizing the proposed views allows one to qualify expressiveness as a quality of interrogation that conveys their content with increased intensity, expressing the speaker's inner state emotionally or logically enhancing the corresponding interrogation. Some works is devoted to the analyses of the phenomenon of intensification as the question of its relation to such concepts as "emotionality", "evaluation, "amplification.

5 Барабанщикова О.Ю. Перепит як стимулятор розвитку діалогу. Проблеми зіставної семантики. Київ, 1999. С. 355-357. DOI.811.111.42(075.8). 
The intensification of echo-questions is achieved by a number of linguistic means that signal a particular position on the intensity scale above the ordinary intensity level. Many works use different terms to define the interpretation of the intensification.

In particular, an intensifier is a term which is used in certain grammatical classification of words belong to the class of adverbs that give the effect of increasing or decreasing the meaning of another element in a sentence. However, the term 'intensifier' does not refer only to the amplifier by which intensification is performed.

Considering the classification of rational evaluation intensifiers, we divide echo-questions into: a) echo-questions that focus the addressee's attention on the objectivity / truth of the information,

In the next dialogue:

Rosie: I know how to expect farmers to work WPA. When you leave to work for them you are doing nothing for your land.

Gant: What land, Rosie? All of our topsoil is probably halfway across the country by now.

Rosie: So what are you and going to do out there on tractor every day? You know you have to work it to keep it all going. (Henley: 86)

And b) echo-questions that focus the attention of the addressee on the importance of the information.

Gant: The usual. Some rumors about a WPA job with Santa Fe. Building a bridge in the Cimmarron River Valley.

Molly: Just rumors?

Gant: No. This one seems to be happening. I went over to the WPA office. (Henley: 86)

In this dialogue the echo-question intensifier Just is used to help the speaker to indicate the significance of the information.

Intensifiers of echo-questions can be divided into the following types ${ }^{6}$ :

1) inner intensifiers of echo-questions which can be expressed by different part of speech;

2) outside intensifiers which can be expressed by different types of sentences;

In the next dialogue:

Big Daddy: Going to cut loose and have what it is they call it have me a ball!

Brick: A ball, huh?

Big Daddy: right, a ball, a ball! Ytll! Hell - I slept with Big Mama till, let's see, five years ago, till I was sixty and she was fifty-eight, and never even liked her, never did! (T. Williams: 95)

${ }^{6}$ Рубинштейн С.Л. Функции и структура. Очерки. Воспоминания. Материальл. Москва, 1989. C. 365-366. DOI.811.11. 
The inner intensifiers $A$ and $h u h$ are used to force the significance of the echo-question ball which clarifies the information.

Intensifiers can be expressed by conjunctions. In the next dialogue:

Brooks: What about beer?

Richard: And what?

Eddie: A beer? (J.Levy: 100)

the inner intensifier of echo-question what? is expressed by the conjunction And.

In the next dialogue:

Fanny. Well, Martha, her daughter, married Teck de Brancovis. Count de Brencovic. He was fancy when she married him. Not so fancy now, I suspect. You know what I mean, the way they are in Europe. Well, they've here.

Sara.What's David like now?

Fanny. Like? Like? I don't know. He's lawyer. You know that. Papa's firm. He's never married. You know Chat too. (Hellman: 247)

The outside intensifier I don't know is expressed by the negative sentence and intensifies the importance of using this eho-question in the dialogue.

In the next dialogue:

Ben's voice. Uncle Willie. It's Ben.

Willie. Ben? Is that you?

Ben's Voice. Yes. Open up. (Simon: 324)

The outside intensifier Is that you? intensifies the intention of echoquestion Ben? which expresses astonishment.

In the next dialogue:

George. How about right now?

Jennie. Right now? That's crazy.

George. You mean, not possible?

Jennie. Oh, it's possible. It's just crazy. (Simon: 662)

the outside intensifier That's crazy is used to intensify the inner state of the speaker.

It should be noted that the intensification of echo-questions requires further research in pragmatic speech.

\section{CONCLUSIONS}

Thus, echo-questions are used to express the inner emotions and feelings of the speaker $\mathrm{s}$ which help them to communicate more deeply. Echoquestions as a pragmatic means can help speakers to be polite and diplomatic. We can note that considering the features of speech and taking into account the features of politeness of echo-questions we can distinguish such types of echo-questions as echo-questions directives which express

The usage of echo-questions in speech plays an important role and allows speakers to communicate with using of echo-questions which makes the speech more interesting and diplomatic. Different types of echo-questions 
and their need the further research analyzing their pragmatic aspect and pointing out their different types using pragmatic elements.

We can admit that contact between speakers is focused on the usage of pragmatic means of speech and is achieved with the intention of echoquestions.

Usage of echo-question in speech is important because it helps to analyze it deeply researching the pragmatic aspect of it following different intentions.

The relations between speakers in speech are different and we can admit that they can use different types of echo-questions which can influence on their attitude to the speech. The direction of the speech depends on their communicative statues because the main role belongs to that speaker who not only creates the phrase but tries to promote different directions of the situation and to appreciate in the pragmatic aspect.

Echo-questions can be used by different speakers and they can follow different intentions in the speech. They can express positive and negative emotions and feelings which help to show the pragmatic features of the speech.

They can be used for filling of communicative pause of the speech and for clarification of information.

The usage of echo-questions in the speech is important because they help us to improve and make it more polite and diplomatic.

\section{SUMMARY}

The article deals to the study of echo-questions and their importance in the speech. Echo-questions in speech are used to express the inner emotions and feelings of the speakers which helps them communicate more deeply. Echo-questions as a pragmatic and linguistic means can help speakers to be polite and diplomatic. We can admit that taking into account the features of politeness of echo-questions we can distinguish such types of echo-questions as echo-questions directive which express an order, request and etc. and echo-questions expressive

Echo-questions can be used by different speakers following different intentions.

They can be used in the dialogue speech expressing different emotions and feelings and can be used for filling of communicative pause and clarification of information. The usage of echo-questions for expressing not interrogative meanings is carried out with helping of hiding of the interrogative meanings because echo-questions can be used for wide range of pragmatic functions.

Echo-questions are researched in speech according to the pragmatic relations between the sender of information and the addressee. 


\section{REFERENCES}

1. Арутюнова Н.Д. Диалогическая цитация (К проблеме чужой речи). Вопросы языкознания. 1989. № 1. С. 50-64. DOI.811.111'42(075.8)

2. Рубинштейн С.Л. Функции и структура. Очерки. Воспоминания. Материалы. Москва, 1989. C. 365-366. DOI.811.11

3. Серль Р.Дж. Косвенные речевые акты. Новое в зарубежной лингвистике. Москва, 1986. Вып. 17. C. 195-222. DOI.811.11

4. Чхетиани Т.Д. Контакто поддерживающая функция метакоммуникативных вопросов. Высказывание $u$ дискурс 6 прагмалистическом аспекте. Киев, 1989. C. 100-103. DOI.81'367.322

5. Барабанщикова О.Ю. Перепит як стимулятор розвитку діалогу. Проблеми зіставної семантики. Київ, 1999. С. 355-357. DOI.811.111.42(075.8).

Information about author: Artemenko A. I., Senior Lecturer of Foreign Languages Department Kyiv National Economic University named after Vadym Hetman 54, Peremohy Street, Kyiv, 49200, Ukraine 